\title{
Erratum: Biography for Contributing Author not Included in 15:3
}

İhsan Sabuncuoğlu is a Professor of Industrial Engineering at Bilkent University. He received B.S. and M.S. degrees in Industrial Engineering from Middle East Technical University and a $\mathrm{PhD}$ degree in Industrial Engineering from the Wichita State University. Associate Professor Sabuncuoğlu teaches and conducts research in the areas of simulation, scheduling, and manufacturing systems. He has published papers in IIE Transactions, Decision Sciences, Simulation, International Journal of Production Research, International Journal of Flexible Manufacturing Systems, International Journal of Computer Integrated Manufacturing, Computers and Operations Research, European Journal of Operational Research, International Journal of Production Economics, Production Planning \& Control, Journal of Operational Research Society, Journal of Intelligent Manufacturing, Computers and Industrial Engineering. He is on the Editorial Board of International Journal of Operations and Quantitative Management, Journal of Operations Management, International Journal of Computer Integrated Manufacturing, and Associate Editor of Transactions on Operational Research. He is also an associate member of Institute of Industrial Engineering and Institute for Operations Research and the Management Science. 